\title{
Biological assessment of the headwater rivers of Opa Reservoir, lle-Ife, Nigeria, using ecological methods
}

\author{
Olanrewaju O. Aliu', Emmanuel O. Akindele $2^{2^{*}}$ (I) and Israel F. Adeniyi ${ }^{2}$
}

\begin{abstract}
Background: Headwater streams and small rivers within a catchment basin contribute greatly to the overall physico-chemical and biological quality of downstream larger freshwater systems; hence, there is a need to continually assess the water quality of such smaller systems. In this study, the three major tributaries (Obudu, Opa, and Esinmirin rivers) of a tropical reservoir were assessed for their water quality using some selected water and sediment parameters, as well as their macroinvertebrate faunae.

Results: All the measured water parameters were found to be within the recommended standards for freshwater life in the three rivers, except for $\mathrm{PO}_{4}{ }^{3-}$ and dissolved oxygen in Opa River which was possibly due to anthropogenic factors. The bottom sediment of the rivers was predominantly sandy and generally low in chemical characteristics. A total of 17 species of macroinvertebrates were recorded in this study: 14 species in Obudu River, 12 species in Esinmirin River, and 11 species in Opa River. Diversity (Margalef and Shannon-Wiener) and Pielou's evenness indices were all low and indicative of an impaired freshwater system, with the lowest indices recorded in the Esinmirin River. Some macrobenthic environmental indicators of poor water quality (e.g., Tubifex sp., Tipula sp., Chironomus sp., Bulinus globosus, and Eristalis sp.) were exclusively recorded in the Esinmirin and/or Obudu River.

Conclusion: The study concludes that the reservoir's headwaters were moderately polluted and had a tendency to become severely polluted by anthropogenic activities along the rivers. Measures should be put in place to reduce environmental impact on the quality of the headwaters and by implication, the reservoir.
\end{abstract}

Keywords: Headwaters, Macroinvertebrates, Sediments, Tributaries, Water quality

\section{Introduction}

Headwater streams or rivers have been defined as the first $2.5 \mathrm{~km}$ of a watercourse from its most distant upstream source. They are also defined as streams which order range from 1 to 3 (Brown \& Brussock, 1991; Furse, 2000; Vuori, Joensuu, et al., 1998). A very good number of headwater streams are located in rural areas in which the predominant anthropogenic influence is farming and washing. Though located in rural areas, it has been reported that such headwater streams are not immune to environmental stress, and such stresses can be further

\footnotetext{
* Correspondence: eoakindele@oauife.edu.ng

${ }^{2}$ Department of Zoology, Obafemi Awolowo University, lle-lfe, Nigeria

Full list of author information is available at the end of the article
}

exacerbated by the small size and low discharge of the streams which reduce their capacity to buffer pollution stress or resist drought (Furse, 2000; Giles, Phillips, \& Barnard, 1991; Wright et al., 1984). Despite the small size of headwater streams and vulnerability to drought and pollution stress, they have been of great conservation importance by contributing significantly to the overall species richness of river systems, by conserving individual species and eventually the overall catchment biodiversity (Furse, 2000). Although headwater streams are typically not characterized by high species richness of macroinvertebrates (e.g., Akindele \& Olutona, 2015; Vannote, Minshall, Cummins, Sedell, \& Cushing, 1980), 
they have been described as biodiversity hotspots for rare or threatened species (Furse, 2000).

Ecological method has been proposed as one of the five main approaches for biological assessment of surface freshwaters; others being physiological and biochemical methods, toxicity tests or bioassays, biological accumulation, and histological/morphological methods (Friedrich, Chapman, \& Beim, 2006). Ecological method of assessing water quality is hinged on two factors, i.e., community structure and indicator species. The community structure reflects the numerical abundance of each species in an aquatic habitat, and it typically consists of many indices (e.g., Shannon-Wiener diversity index, Margalef index, and Pielou's evenness index). On the other hand, an indicator organism is a species selected for its sensitivity or tolerance to different kinds of pollution or environmental stressors (Friedrich et al., 2006). Among others, benthic invertebrates have been more used by hydrobiologists than any other group of aquatic organisms, in developing ecological methods for water quality assessment (Friedrich et al., 2006; Voshell, 2002). The suitability of benthic macroinvertebrates in interpreting ecological conditions of running waters is owing to the fact that most members are sessile, relatively long-lived, occur all year long, and are in contact with sediments. They are also preferred to any other group of organisms because they are more easily collected, handled, and reliably identified (Friedrich et al., 2006; Rosenberg \& Resh, 1993). Contamination and toxicity of sediments will therefore affect those benthic organisms that are sensitive to them (Friedrich et al., 2006).

Despite the fact that headwater streams are important national resource, they are under-reported in ecological studies or monitoring programs (Furse, 2000). Often times, limnological studies are focused on larger freshwater systems like reservoirs and rivers, with little or no attention on their tributaries or headwaters (Akindele \& Olutona, 2015). In the study of macroinvertebrates of a South African river system (Buffalo River), a total of 12 macroinvertebrate taxa were exclusively found in its headwater (Palmer, Palmer, et al., 1994). In the same vein, Akindele and Olutona (2015) reported a total of 23 macroinvertebrate taxa in the headwater streams of a Nigerian reservoir as against a total of 9 taxa that had earlier been reported by Atobatele and Ugwumba (2010) on the same reservoir. These suggest that macroinvertebrate taxa of some freshwater systems may be exclusively confined to their headwaters (Furse, 2000). In view of the foregoing, an ecological approach was employed to assess the biological water quality of the headwater rivers of an artificial tropical lake (reservoir). This was based on the water quality of headwater rivers, sediment characteristics, and macroinvertebrate composition/community structure. This was with a view to ascertaining the ecological integrity of the rivers and their implications for the health status of the downstream reservoir.

\section{Materials and methods \\ Study area}

This study was carried out on the major tributaries (headwater rivers) of Opa Reservoir in Ile-Ife, Osun State, Nigeria, i.e., Opa, Obudu, and Esinmirin rivers. Opa Reservoir is located on the campus of Obafemi Awolowo University, Ile-Ife, Nigeria, and it provides several ecosystem services to the university community. The drainage basin of the reservoir falls roughly between $07^{\circ} 27^{\prime}-07^{\circ} 35^{\prime} \mathrm{N}$ and $004^{\circ} 32^{\prime}-004^{\circ} 39^{\prime} \mathrm{E}$. The three headwater rivers are located in Ife Central and Atakumosa Local Governments in Osun State, Nigeria. The study area is characterized by two distinct seasons, viz., the dry season (November-March) and the rainy season (April-October) (Akintola, 1986).

\section{Field sampling and in-situ determinations}

A total of 16 sampling stations were established for this study: six stations each on Obudu and Esinmirin rivers and four stations on Opa River (Fig. 1). Stream orders in Obudu River include "2," "3," and "4"; those of Esinmirin were "2" and "3"; those of Opa River were "3"and "4." Samples were collected from September 2004 to July 2005 , with the aim of capturing early and late periods of both dry and rainy seasons (i.e., September 2004, December 2004, March 2005, May 2005, and July 2005). Composite samples of bottom sediments were collected at each sampling station using a grab sampler and subsequently stored inside well-labeled polyethylene bags. Samples of macroinvertebrates were also collected by using a sieve of mesh size $0.5 \mathrm{~mm}$ and preserved immediately in $5 \%$ formalin solution. Water samples were collected inside clean plastic containers which had also been rinsed with the water sample. Electrical conductivity (EC) and $\mathrm{pH}$ of water samples were determined on the field using a Jenway conductivity meter and Lovibond $\mathrm{pH}$ comparator, respectively. Dissolved oxygen (DO) samples were collected in $250 \mathrm{ml}$ amber bottles and fixed on the field using Winkler's reagents. In the same vein, biological oxygen demand (BOD) samples were also collected in dark amber bottles and taken to the laboratory for incubation over a period of 5 days, hence the term $\mathrm{BOD}_{5}$.

\section{Laboratory analysis and biodiversity indices}

The following water parameters were analyzed in the laboratory using the appropriate titrimetric or instrumentation methods as described by the American Public Health Association APHA, AWMA, and WPCF (1995): $\mathrm{DO}, \mathrm{BOD}_{5}$, total alkalinity, acidity, organic carbon, $\mathrm{NO}_{3}{ }^{-}, \mathrm{PO}_{4}{ }^{3-}$, calcium, and magnesium. Particle size distribution of each sediment sample was determined using 


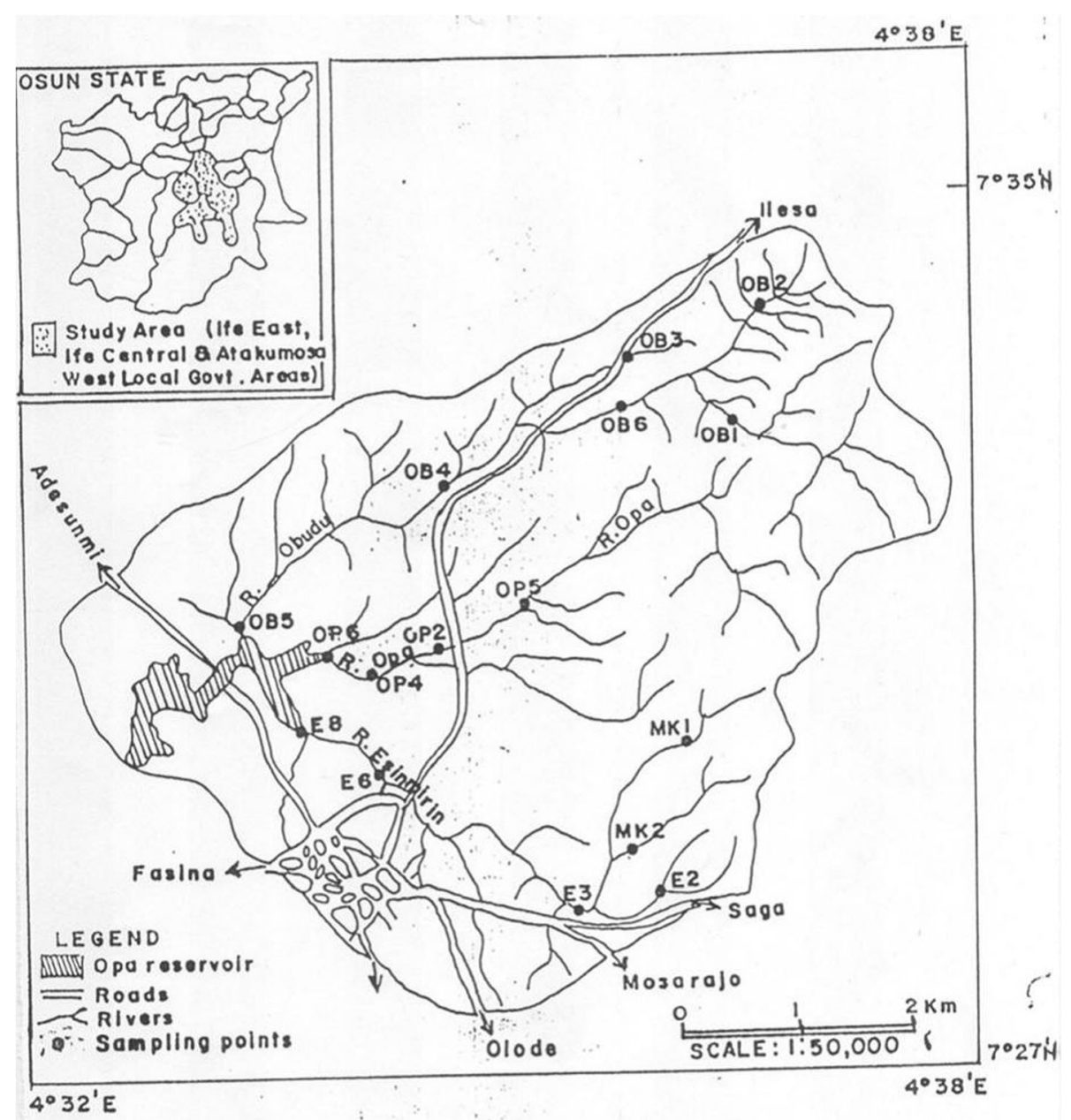

Fig. 1 Map of the study area and drainage basin of Opa Reservoir's tributaries (inset: map of Osun State, Nigeria, showing the location of the study area)

the Bouyocus method. The following sediment characteristics were also determined using appropriate laboratory methods as described by APHA, AWMA, and WPCF (1995): $\mathrm{pH}, \mathrm{EC}$, organic carbon, $\mathrm{Ca}^{2+}, \mathrm{Mg}^{2+}$, $\mathrm{NO}_{3}{ }^{-}, \mathrm{PO}_{4}{ }^{3-}$, and $\mathrm{SO}_{4}{ }^{2-}$. Specimens of macroinvertebrates were first sorted out into broad taxonomic groups based on their distinctive morphological features, e.g., Annelida, Gastropoda, and Insecta. Specimens that were too small to be identified with naked eyes were observed under a binocular microscope and identified using the identification keys (e.g., Abbott \& Morris, 1995; Bouchard, 2004; Brown, 1980). Biodiversity of macroinvertebrates in the three rivers was determined using the following indices: Margalef diversity index (Lenat, Smock, \& Penrose, 1980), Shannon-Wiener diversity index, and Pielou's evenness index (Shannon, 1948).

\section{Statistical analysis}

Descriptive statistics (mean, standard deviation, standard error of mean) were used to summarize the data recorded during laboratory analysis. The dataset was also tested for normality with Shapiro-Wilk test, in order to ascertain the appropriate statistical tests for the analysis (i.e., parametric or non-parametric tests). The dataset was parametric, hence the use of one-way analysis of variance (ANOVA) for variations in the parameters among the three rivers. Pearson's correlation was also used to establish the relationships between macroinvertebrates and the independent variables (water and sediment parameters).

\section{Results}

Water and sediment physicochemical parameters

Table 1 provides the mean values for water parameters in the three rivers. Electrical conductivity, $\mathrm{pH}$, total alkalinity, $\mathrm{Ca}^{2+}$, and $\mathrm{Mg}^{2+}$ all recorded their lowest and highest values in Obudu and Esinmirin rivers, respectively. Dissolved oxygen recorded its lowest and highest values at Opa and Obudu rivers, respectively. Lowest value of organic carbon was recorded at both Opa and Esinmirin 
Table 1 Physico-chemical parameters of water in Opa Reservoir's tributaries (September 2004-July 2005)

\begin{tabular}{|c|c|c|c|c|c|}
\hline \multirow[t]{2}{*}{ Water parameter } & \multicolumn{3}{|l|}{ River system } & \multicolumn{2}{|c|}{ ANOVA } \\
\hline & Obudu & Opa & Esinmirin & $\mathrm{F}$ & $p$ \\
\hline Water temperature $(\mathrm{C})$ & $26.14 \pm 0.95$ & $26.23 \pm 0.65$ & $26.37 \pm 1.43$ & 0.050 & 0.952 \\
\hline $\mathrm{pH}$ & $7.30 \pm 0.14$ & $7.31 \pm 0.16$ & $7.57 \pm 0.17$ & 4.660 & 0.048 \\
\hline $\mathrm{EC}(\mu \mathrm{S} / \mathrm{cm})$ & $122.59 \pm 12.58$ & $170.76 \pm 77.57$ & $207.89 \pm 68.62$ & 4.576 & 0.071 \\
\hline $\mathrm{DO}(\mathrm{mg} / \mathrm{L})$ & $5.31 \pm 0.71$ & $4.62 \pm 0.68$ & $5.11 \pm 1.01$ & 1.221 & 0.345 \\
\hline $\mathrm{BOD}_{5}(\mathrm{mg} / \mathrm{L})$ & $1.71 \pm 0.40$ & $1.72 \pm 0.60$ & $2.21 \pm 0.71$ & 1.156 & 0.367 \\
\hline Total alkalinity $\left(\mathrm{mgCaCO}_{3} / \mathrm{L}\right)$ & $44.16 \pm 7.46$ & $56.50 \pm 37.42$ & $77.50 \pm 35.90$ & 2.351 & 0.186 \\
\hline Total acidity $\left(\mathrm{mgCaCO}_{3} / \mathrm{L}\right)$ & $25.50 \pm 3.78$ & $25.00 \pm 4.54$ & $26.83 \pm 6.01$ & 0.149 & 0.864 \\
\hline Organic carbon (mg/L) & $2.82 \pm 1.03$ & $2.02 \pm 1.16$ & $2.02 \pm 0.63$ & 1.19 & 6.751 \\
\hline $\mathrm{Ca}^{2+}(\mathrm{mg} / \mathrm{L})$ & $9.58 \pm 2.06$ & $15.50 \pm 7.77$ & $20.96 \pm 7.26$ & 6.824 & 0.032 \\
\hline $\mathrm{Mg}^{2+}(\mathrm{mg} / \mathrm{L})$ & $2.23 \pm 0.69$ & $3.65 \pm 2.75$ & $7.37 \pm 4.04$ & 4.551 & 0.070 \\
\hline $\mathrm{NO}_{3}^{-}(\mathrm{mg} / \mathrm{L})$ & $1.26 \pm 0.21$ & $1.27 \pm 0.22$ & $1.14 \pm 0.23$ & 0.564 & 0.591 \\
\hline $\mathrm{PO}_{4}^{3-}(\mathrm{mg} / \mathrm{L})$ & $0.71 \pm 0.28$ & $0.51 \pm 0.21$ & $0.26 \pm 0.09$ & 7.83 & 0.022 \\
\hline
\end{tabular}

while the highest was at Obudu River. Esinmirin River recorded the lowest values of $\mathrm{NO}_{3}{ }^{-}$and $\mathrm{PO}_{4}{ }^{3-}$ while the corresponding highest values for both parameters were at Opa and Obudu rivers, respectively. Only three parameters (i.e., $\mathrm{pH}, \mathrm{Ca}^{2+}$, and $\mathrm{PO}_{4}{ }^{3-}$ ) showed significant differences $(p<0.05)$ in their variations among the three rivers. Biological oxygen demand and total acidity showed no distinct trend and significant difference among the rivers, though their highest values were both recorded at the Esinmirin River. In the sediment, $\mathrm{pH}$ and $\mathrm{PO}_{4}{ }^{3-}$ both recorded their lowest and highest values at Opa and Esinmirin rivers, respectively (Table 2). Electrical conductivity was lowest at Obudu River and highest at Esinmirin River, while $\mathrm{SO}_{4}{ }^{2-}$ recorded its lowest and highest at Obudu and Opa rivers, respectively. Other parameters (organic carbon and $\mathrm{NO}_{3}{ }^{-}$) showed no definite trend in their variations. In all, only EC showed significant difference $(p<0.01)$ in its spatial variation among the river's sediments. Percentage textural composition of the sediment is shown in Fig. 2. Sand was the dominant textural class in the three rivers, followed by clay, and then silt. However, it was observed that the percentage composition of sand decreased from the upper to the lower reach of the rivers, while the reverse was the case for silt and clay (data not shown).

\section{Benthic macroinvertebrates of the rivers and their relationships with water and sediment parameters}

The benthic macroinvertebrates recorded in this study comprised of a total of 17 species which represented three phyla (Arthropoda, Mollusca, and Annelida (Table 3)). The fauna also comprised of four major groups (Crustacea, Insecta, Gastropoda, and Annelida) which were all represented in the three rivers except for Annelida which only occurred in Obudu River. Obudu River recorded the highest taxa richness while Esinmirin River recorded the highest abundance. In both cases (i.e., taxa richness and abundance), Opa River recorded the lowest. In the overall, insects dominated the taxa composition of the fauna (i.e., $60 \%$ ), followed by gastropods (30\%) while crustaceans and annelids were each monospecific (10\% each) (Fig. 3). Insecta recorded the highest taxa composition in Obudu River (eight spp.), followed by Esinmirin (six spp.) and Opa rivers (five spp.). Opa and Esinmirin rivers each recorded five species of gastropods while Obudu River recorded four species. Gastropoda dominated the fauna in

Table 2 Sediment characteristics of Opa Reservoir's tributaries (September 2004-July 2005)

\begin{tabular}{|c|c|c|c|c|c|}
\hline \multirow{2}{*}{$\begin{array}{l}\text { Sediment } \\
\text { parameter }\end{array}$} & \multicolumn{3}{|l|}{ River system } & \multicolumn{2}{|c|}{ ANOVA } \\
\hline & Obudu & Opa & Esinmirin & $\mathrm{F}$ & $p$ \\
\hline$\overline{\mathrm{pH}}$ & $6.72 \pm 0.78$ & $6.59 \pm 0.67$ & $7.10 \pm 0.40$ & 1.165 & 0.364 \\
\hline $\mathrm{EC}(\mu \mathrm{S} / \mathrm{cm})$ & $104.61 \pm 23.53$ & $162.21 \pm 63.19$ & $184.23 \pm 29.33$ & 10.64 & 0.007 \\
\hline Organic carbon (\%) & $0.06 \pm 0.02$ & $0.07 \pm 0.02$ & $0.06 \pm 0.02$ & 0.213 & 0.813 \\
\hline $\mathrm{NO}_{3}^{-}(\mathrm{mg} / \mathrm{L})$ & $2.01 \pm 0.96$ & $2.00 \pm 1.61$ & $1.62 \pm 0.87$ & 0.239 & 0.792 \\
\hline $\mathrm{PO}_{4}{ }^{3-}(\mathrm{mg} / \mathrm{L})$ & $16.97 \pm 11.24$ & $15.37 \pm 8.94$ & $18.73 \pm 4.87$ & 0.263 & 0.776 \\
\hline $\mathrm{SO}_{4}{ }^{2-}(\mathrm{mg} / \mathrm{L})$ & $39.63 \pm 8.25$ & $51.55 \pm 16.49$ & $49.60 \pm 10.97$ & 1.713 & 0.244 \\
\hline
\end{tabular}




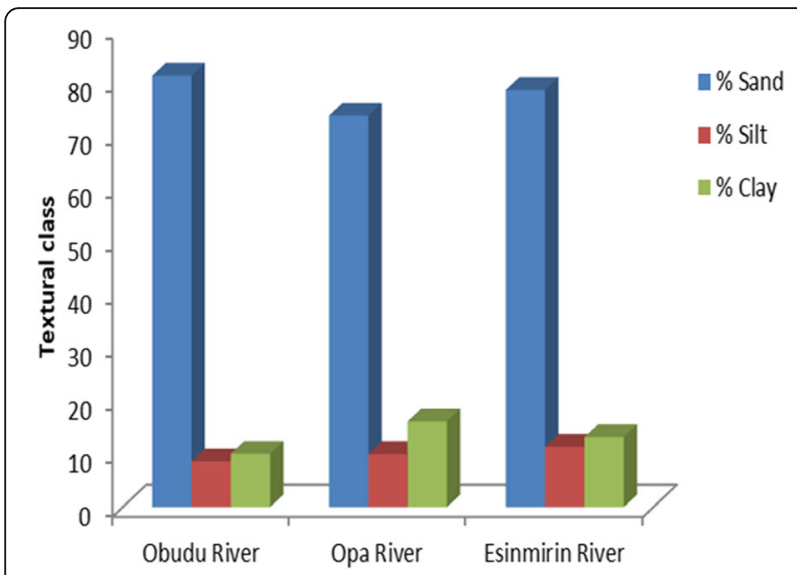

Fig. 2 Textural composition of sediments in Obudu, Opa, and Esinmirin rivers ( $n=6$ in Obudu River, $n=4$ in Opa River, and $n=6$ in Esinmirin River)

Table 3 Macroinvertebrate composition, distribution, and community structure in Opa Reservoir's tributaries (September 2004-July 2005)

\begin{tabular}{|c|c|c|c|c|}
\hline$S / N$ & Taxon & Obudu River & Opa River & $\begin{array}{l}\text { Esinmirin } \\
\text { River }\end{array}$ \\
\hline & \multicolumn{4}{|l|}{ Crustacea } \\
\hline \multirow[t]{2}{*}{1} & Sudanonautes africanus & 113 & 106 & 89 \\
\hline & \multicolumn{4}{|l|}{ Insecta } \\
\hline 2 & Elassoneuria sp. & 123 & 18 & 6 \\
\hline 3 & Aciagrion hamoni & 0 & 18 & 0 \\
\hline 4 & Lestinogomphus sp. & 148 & 36 & 30 \\
\hline 5 & Urothermis assignata & 118 & 44 & 88 \\
\hline 6 & Acisoma panorpoides & 159 & 59 & 18 \\
\hline 7 & Diptera 1 & 6 & 0 & 0 \\
\hline 8 & Diptera 2 & 6 & 0 & 0 \\
\hline 9 & Chironomus sp. & 6 & 0 & 58 \\
\hline \multirow[t]{2}{*}{10} & Eristalis sp. & 6 & 0 & 6 \\
\hline & \multicolumn{4}{|l|}{ Gastropoda } \\
\hline 11 & Lanistes libycus & 90 & 24 & 36 \\
\hline 12 & Potadoma moerchi & 18 & 18 & 0 \\
\hline 13 & Potadoma freethi & 12 & 83 & 889 \\
\hline 14 & Melanoides tuberculata & 142 & 48 & 439 \\
\hline 15 & Bulinus globosus & 0 & 0 & 93 \\
\hline \multirow[t]{2}{*}{16} & Tagelus plebeius & 0 & 12 & 12 \\
\hline & \multicolumn{4}{|l|}{ Annelida } \\
\hline 17 & Tubifex sp. & 47 & 0 & 0 \\
\hline \multicolumn{2}{|c|}{ Taxa richness } & 14 & 11 & 12 \\
\hline \multicolumn{2}{|c|}{ Abundance } & 994 & 466 & 1764 \\
\hline \multicolumn{2}{|c|}{ Margalef diversity index } & 1.884 & 1.628 & 1.472 \\
\hline \multicolumn{2}{|c|}{ Shannon-Wiener index } & 2.225 & 2.185 & 1.527 \\
\hline \multicolumn{2}{|c|}{ Pielou's evenness index } & 0.661 & 0.808 & 0.384 \\
\hline
\end{tabular}

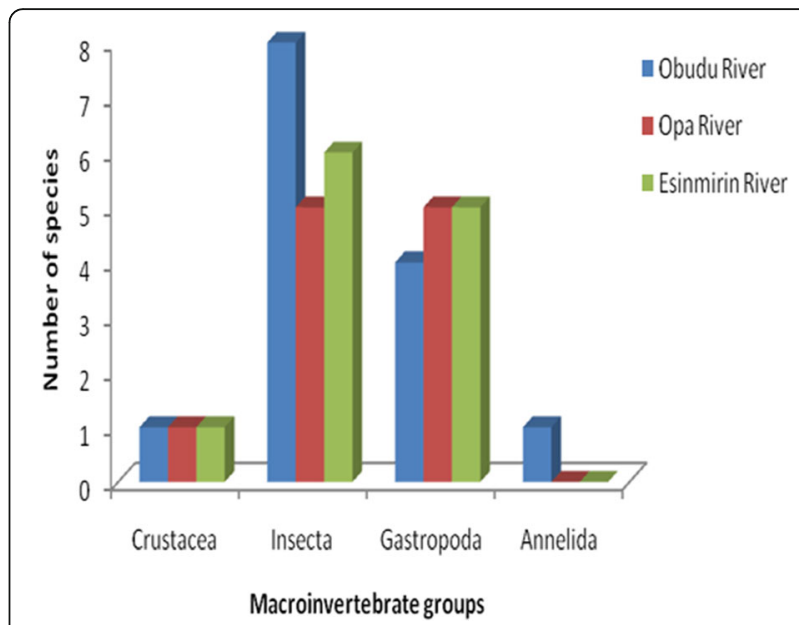

Fig. 3 Taxa richness of the dominant groups of macroinvertebrates in Obudu, Opa, and Esinmirin rivers

terms of abundance (68\%), followed by Insecta (23\%), Crustacea (8\%), and Annelida (1\%). The order of dominance of the major groups in each river system was somewhat similar to the earlier reported general trend above except in Obudu River where Insecta outnumbered Gastropoda (Fig. 4). One-way ANOVA indicated no significant difference $(p>0.05)$ in both taxa richness and abundance of macroinvertebrates among the three rivers. The highest macroinvertebrate diversity indices (i.e., Margalef and Shannon-Wiener) were in each case recorded in Obudu River, followed by Opa River while the lowest diversity indices were recorded in Esinmirin River. Evenness of species recorded its highest value at Opa River, followed by Obudu while the lowest evenness was again recorded

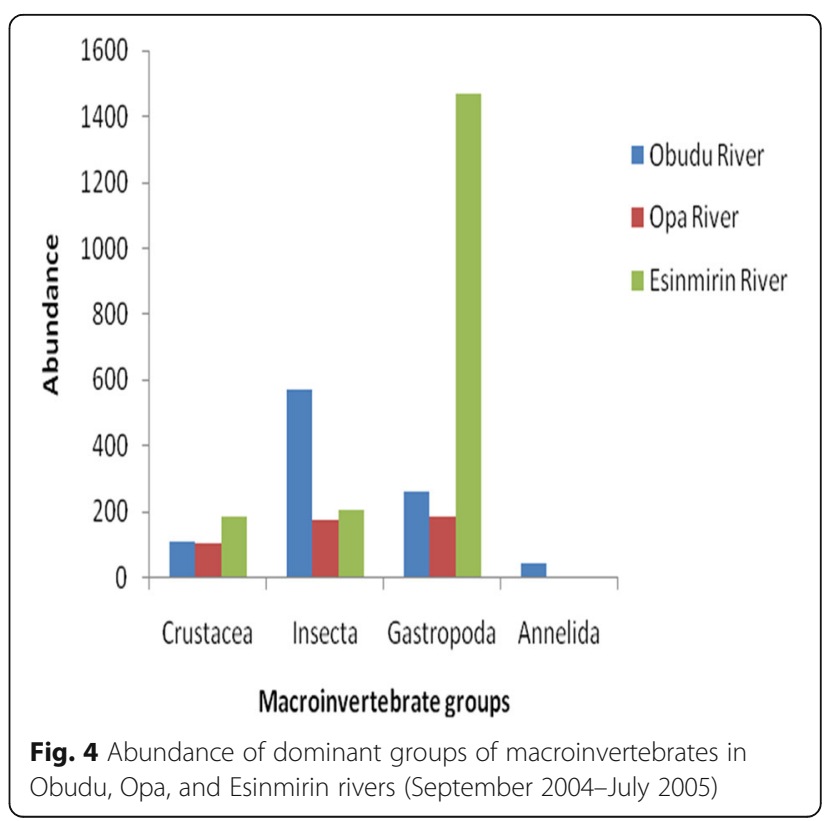


at Esinmirin River. The most dominant species was Potadoma freethi which recorded nearly 1000 individuals in the three rivers, followed by Melanoides tuberculata.

The relationships between water/sediment parameters and biodiversity indices, i.e., taxa richness, abundance, Margalef diversity (D) index, Shannon-Wiener diversity $(\mathrm{H})$ index, and evenness index in Obudu River, indicated significant correlations in three cases only. Water acidity showed significant negative correlations with both taxa richness $(r=-0.936, p=0.006)$ and Margalef diversity index $(\mathrm{r}=-0.908, \mathrm{p}=0.012)$, while sediment $\mathrm{pH}$ showed a significant positive correlation with evenness $(r=$ $0.938, p=0.019)$. Only one water parameter $\left(\mathrm{PO}_{4}{ }^{3-}\right)$ recorded a significant correlation with any biodiversity index (i.e., evenness) in Opa River $(r=0.986, p=0.014)$. However, $\mathrm{SO}_{4}{ }^{2-}$ in the river's sediment showed significant correlations with taxa richness $(r=0.897, p=$ $0.039)$, abundance $(r=0.875, p=0.050)$, and Margalef index $(r=0.903, p=0.036)$. Conversely, organic carbon in the sediment recorded negative correlations with taxa richness $(r=-0.887, p=0.045)$, abundance $(r=-$ 0.926, $p=0.024)$, and Margalef index $(r=-0.872, p=$ 0.050). In Esinmirin River, more water parameters showed significant correlations with biodiversity indices than in other rivers. Organic carbon and $\mathrm{pH}$ showed significant positive correlations with abundance $(r=0.949$, $p=0.003$ and $r=0.850, p=0.032$, respectively). Dissolved oxygen showed significant negative correlations with taxa richness $(r=-0.939, p=0.005)$ and abundance $(r=-0.907, p=0.012)$. A significant negative correlation $(r=-0.846, p=0.033)$ was also recorded between BOD and evenness of species. For the sediment, significant negative correlations were recorded between $\mathrm{SO}_{4}{ }^{2-}$ and taxa richness $(r=-0.901, p=0.037)$ as well as Margalef index $(r=-0.916, p=0.029)$.

\section{Discussion}

Most of the selected water parameters in the three rivers were within their recommended standards for aquatic life support, e.g., total organic carbon $<10 \mathrm{mg} / \mathrm{L}$, BOD 3.0-6.0 mg/L, $\mathrm{NO}_{3}{ }^{-}<5 \mathrm{mg} / \mathrm{L}$, and $\mathrm{pH} 6.0-8.5$ (Chapman \& Kimstach, 2006). The only exceptions were for $\mathrm{PO}_{4}{ }^{3-}$ in the three rivers and DO in the Opa River. Phosphate concentration in the rivers exceeded the recommended $0.1 \mathrm{mg} / \mathrm{L}$ upper limit for freshwaters (Michaud, 1991; Moore, 1987). The mean dissolved oxygen concentration in Opa River was below $5 \mathrm{mg} / \mathrm{L}$ which is the minimum requirement for proper functioning and survival of biological communities, as recommended by Chapman and Kimstach (2006). Sediment characteristics of the rivers compared favorably with similar studies in Nigeria (e.g., Akindele \& Olutona, 2015; Mbagwu, 1989; Nathaniel, 2001). The bottom sediment is dominantly sand, low in nutrient compounds, and physico-chemical characteristics. The sediment textural composition and particle grain size are also a reflection of the bedrock formation within the basin (Smith \& Montgonery, 1962).

The number of macroinvertebrate species recorded in this study was rather too small for rivers of such orders (i.e., 2-4 orders). Studies carried out in similar water bodies had reported higher number of species or taxa. Among such were the studies of Kelly-Quinn et al. (2003) who reported a total of 80 macroinvertebrate taxa in Caher River (Ireland) and Garn, Scudder, Richards, and Sullivan (2001) who reported 48 species in Wolf River (Winscosin). Others include the studies of Ogbeibu and Oribhabor (2002) on a fourth order stream in Nigeria who reported a total of 43 macroinvertebrate taxa and Akindele, Adeniyi, Oyeku, and Adu (2018) who reported a total of 27 macroinvertebrate taxa in Osun River (Nigeria). The current study however reported a higher number of taxa than what was reported by Nathaniel (2001) on the downstream Opa Reservoir (i.e., 7 taxa). The low number of macroinvertebrate taxa reported in this study can be due to the predominant sand textural composition and poor organic content of the bottom sediment. Five out of the seven taxa previously reported in Opa Reservoir by Nathaniel (2001) were also reported in this study, i.e., P. moerchi, Lanistes lybicus, Bulinus globosus, Acisoma panorpoides, and Aciagrion hamoni.

Generally, diversity and evenness indices of macroinvertebrates of the reservoir's headwaters indicated an impaired system and poor water quality to support macroinvertebrate faunae. Good water quality that support macroinvertebrate faunae has been well associated with Margalef and Shannon-Wiener indices that are greater than three, while poor water quality is associated with indices less than three (Akindele \& Adeniyi, 2013; Lenat et al., 1980; Mandaville, 2002; Shannon, 1948). Based on these diversity indices (i.e., $D=1.0-3.0$ and $\mathrm{H}<3.0$ ), the three rivers can be considered moderately impacted by anthropogenic (agricultural and commercial) activities, with Esinmirin River very close to being severely impacted. Relative distribution of species (evenness) was comparably much lower in Esinmirin River than either Obudu or Opa River. Some bioindicators of poor water quality (i.e., pollution-tolerant) were recorded in this study and they occurred exclusively in Esinmirin and/or Obudu River. Such species include Tubifex sp., Tipula sp., Chironomus sp., Bulinus globosus, and Eristalis sp. (Alba-Tercedor \& Pujante, 2000; Friedrich et al., 2006). Specifically, B. globosus and Chironomus sp. were exclusively recorded in their numbers in Esinmirin River. This underscores its poorest water quality condition as revealed by diversity and evenness indices. Furthermore, the most dominant species in this study $(P$. freethi) is a pulmonate gastropod and the occurrence and/or dominance of which has been described as an indication of 
poor water quality (Voshell, 2002). As an adaptive measure in oxygen-tensed environments, pulmonates make use of their lung-like apparatus to extract oxygen from the atmosphere (Allaby, 1999; Voshell, 2002). The second most dominant species (M. tuberculata) is a facultative (i.e., can survive in moderately polluted environments) and invasive species (Vogler, Nunez, Gregoric, Beltramino, \& Peso, 2012; Voshell, 2002). It is worth being stated that $P$. freethi and $M$. tuberculata both accounted for nearly $76 \%$ of the faunal abundance in Esinmirin River, hence the low evenness of species in the river. Although the faunal composition and community structure indicated that the rivers were of poor biological water quality, a few bioindicators of good water quality were also recorded in them, i.e., Elassoneuria sp., A. hamoni, Lestinogomphus sp., Urothermis assignata, and A. panorpoides (Alba-Tercedor \& Pujante, 2000). These insect larvae were particularly recorded in large numbers at the upper reaches of the rivers where there was a good riparian vegetation cover. However, their distribution and abundance in the entire stretch of the rivers were not indicative enough to suggest a pristine or near-pristine condition.

\section{Conclusion}

The ecological condition or health status of the three headwater rivers of Opa Reservoir can be considered moderately polluted based on the relative proportion of pollution-tolerant/facultative species to pollutionsensitive species. There is a high tendency that the rivers could become severely polluted through further anthropogenic (agricultural and commercial) activities. This study therefore recommends that Opa Reservoir's headwaters should be adequately monitored. Continuous efforts should be made to regulate anthropogenic activities that could directly impact the quality of the reservoir's headwaters and ultimately improve their ecological status. A similar approach is recommended for impaired headwaters of lakes, reservoir, and larger river systems.

\section{Abbreviations}

APHA: American Public Health Association; ANOVA: Analysis of variance; EC: Electrical conductivity; DO: Dissolved oxygen; $\mathrm{BOD}_{5}$ : Biological oxygen demand $_{5}$

\section{Acknowledgements}

Authors would like to thank Prof. Sylvester S. Ogbogu for his kind assistance in identifying some of the insects recorded in this study.

\section{Authors' contributions}

OOA collated field and laboratory data, analyzed the data, and revised the manuscript. EOA was involved in the field work, analyzed the data and drafted the manuscript. IFA made substantial contributions to conception and design of this study. The author(s) read and approved the final manuscript.

\section{Funding}

Not applicable

\section{Availability of data and materials}

The datasets generated and/or analyzed during the current study are available from the corresponding author on reasonable request.

Ethics approval and consent to participate

Not applicable

\section{Consent for publication}

Not applicable

\section{Competing interests}

The authors declare that they have no competing interests.

\section{Author details}

${ }^{1}$ Institute of Ecology and Environmental Studies, Obafemi Awolowo University, Ile-Ife, Nigeria. ${ }^{2}$ Department of Zoology, Obafemi Awolowo University, lle-Ife, Nigeria.

Received: 1 August 2019 Accepted: 19 March 2020

Published online: 06 April 2020

\section{References}

Abbott, R.T., \& Morris, P.A. (1995). A field guide to shells of the Atlantic and Gulf Coast and the Westlndies, $4^{\text {th }}$ ed. USA: Hoghton Mifflin.

Akindele, E. O., Adeniyi, A. V., Oyeku, O. G., \& Adu, B. W. (2018). Analysis of benthic macroinvertebrates, biological water quality and conservation value of a tropical river and UNESCO-protected environment. African Journal of Ecology, 56, 488-498.

Akindele, E. O., \& Adeniyi, I. F. (2013). Zooplankton composition and community structure in Lake Tiga, Kano, Nigeria. African Journal of Aquatic Science, 38(3), 279-286.

Akindele, E. O., \& Olutona, G. O. (2015). Environmental variables and benthic macroinvertebrate assemblage in the headwater streams of an Afro-tropical Reservoir. Water and Environment Journal, 29, 541-548.

Akintola, J. O. (1986). Rainfall distribution in Nigeria. Ibadan. Nigeria: Impact Publishers (Nig).

Alba-Tercedor, J., \& Pujante, A. M. (2000). Running water biomonitoring in Spain: opportunities for a predictive approach. In J. F. Wright, D. W. Sutcliffe, \& M. T. Furse (Eds.), Assessing the biological quality of freshwaters: RIVPACS and other techniques, (pp. 207-216). Cumbria: Freshwater Biological Association.

Allaby, M. (1999). Oxford dictionary of zoology. Oxford, United Kingdom: Oxford University Press.

APHA, AWMA \& WPCF (1995). Standard methods for the examination of water and wastewater. Washington: APHA.

Atobatele, O. E., \& Ugwumba, O. A. (2010). Distribution, abundance and diversity of macrozoobenthos in Aiba Reservoir, Iwo, Nigeria. African Journal of Aquatic Science, 35(3), 291-297.

Bouchard, R. W. (2004). Guide to aquatic invertebrates of the upper Midwest: identification manual for students, citizen monitors and aquatic resources professionals. USA: Water Resources Centre.

Brown, A. V., \& Brussock, P. P. (1991). Comparison of benthic invertebrates between riffles and pools. Hydrobiologia, 220, 99-108.

Brown, D. S. (1980). Freshwater snails of Africa and their medical importance. London: Taylor and Francis Ltd.

Chapman, D., \& Kimstach, V. (2006). Selection of water quality variables. In D. Chapman (Ed.), Water quality assessments, (pp. 65-122). London: Chapman and Hall.

Friedrich, G., Chapman, D., \& Beim, A. (2006). In D. Chapman (Ed.), Water quality assessments, (pp. 167-227). London: Chapman and Hall.

Furse, M. T. (2000). The application of RIVPACS procedures in headwater streamsan extensive and important national resource. In J. F. Wright, D. W. Sutcliffe, \& M. T. Furse (Eds.), Assessing the biological quality of freshwaters: RIVPACS and other techniques, (pp. 79-91). Cumbria: Freshwater Biological Association.

Garn, H.S., Scudder, B.C., Richards, K.D., \& Sullivan, D.J. (2001). Chemical characteristics of water, sediment and benthic communities of the Wolf River, Menominee, Indian Reservation, Winsconsin. Water Year 1986-96. United States Geological Survey Water Resources Investigation Report 01-4019.

Giles, N., Phillips, V. E., \& Barnard, S. (1991). The current crisis: ecological effects of low flows. Lincoln: Royal Society for Nature Conservation.

Kelly-Quinn, M., Bradley, C., Murray, D., Tierney, D., Ashe, P., Bracken, J., \& McGarrigle, M .(2003) Physico-chemical characteristics and macroinvertebrate 
communities of the Caher River. Biology and Environment: Proceedings of the Royal Irish Academy, 103B46, 187-196.

Lenat, D. R., Smock, L. A., \& Penrose, D. L. (1980). Use of benthic macroinvertebrates as indicators of environmental quality. In L. W. Douglass (Ed.), Biological monitoring for environmental effects, (pp. 97-114). Toronto, ON: Lexington Books.

Mandaville, S. M. (2002). Benthic macroinvertebrates in freshwater - taxa tolerance values, metrics and Protocols. In Project H-1. Nova Scotia: Soil and Water Conservation Society of Metro Halifax.

Mbagwu, I. G. (1989). Preliminary survey of macrozoobenthos of Tiga Lake, Kano Lake. Kano, Nigeria: M.Sc. Thesis, Bayero University.

Michaud, J. P. (1991). A citizen's guide to understanding and monitoring lakes and streams. Publ. \#94-149. Olympia, WA: Washington State Dept of Ecology, Publications Office.

Moore, M.L. (1987). NALMS management guide for lakes and reservoirs. North American Lake Management Society.

Nathaniel, I. T. (2001). The macroinvertebrate benthic fauna and bottom sediment of Opa Reservoir in Obafemi Awolowo University, Ile-Ife, Nigeria. Ile-lfe, Nigeria: M.Phil. Thesis, Obafemi Awolowo University.

Ogbeibu, A. E., \& Oribhabor, B. J. (2002). Ecological impact of river impoundment using benthic macroinvertebrates as indicators. Water Research, 36, 2427-2436.

Palmer, C., Palmer, A., et al. (1994). Macroinvertebrate community structure and altitudinal changes in the upper reaches of a warm, temperate Southern African river. Freshwater Biology, 32, 337-347.

Rosenberg, D., \& Resh, V. (1993). Freshwater biomonitoring and benthic macroinvertebrates. New York: Chapman and Hall.

Shannon, C. (1948). A mathematical theory of communication. Bell Systems Technical Journal, 27, 379-423.

Smith, A. J., \& Montgonery, R. F. (1962). Soil and land use of Central Western Nigeria. Ibadan, Nigeria: Government Printer.

Vannote, R. L., Minshall, G. W., Cummins, K. W., Sedell, J. R., \& Cushing, C. E. (1980), The river continuum concept. Canadian Journal of Fisheries and Aquatic Science, 37, 130-137.

Vogler, R. E., Nunez, V., Gregoric, D. E. G., Beltramino, A. A., \& Peso, J. G. (2012). Melanoides tuberculata: the history of an invader snail. In E. M. Hamalainen, \& S. Jarvinen (Eds.), Snails: biology, ecology and conservation, (pp. 65-84). New York: Nova Science Publishers Inc.

Voshell, J. R. (2002). A guide to common freshwater invertebrates of North America. Granville, OH: The McDonald and Woodward Publishing Company.

Vuori, K. M., Joensuu, I., et al. (1998). Forest drainage: a threat to benthic biodiversity of boreal headwater streams? Aquatic Conservation: Marine and Freshwater Ecosystems, 8, 745-759.

Wright, J. F., Hiley, P. D., Cooloing, D. A., Cameron, A. C., Wigham, M. E., \& Berrie, A. D. (1984). The invertebrate fauna of a small chalk stream in Berkshire, England, and the effect of intermittent flow. Archiv fur Hydrobiologie, 99, 176-199.

\section{Publisher's Note}

Springer Nature remains neutral with regard to jurisdictional claims in published maps and institutional affiliations.

\section{Submit your manuscript to a SpringerOpen ${ }^{\circ}$ journal and benefit from:}

- Convenient online submission

- Rigorous peer review

- Open access: articles freely available online

- High visibility within the field

- Retaining the copyright to your article

Submit your next manuscript at $\boldsymbol{\nabla}$ springeropen.com 